\title{
Future Challenges of Education for Children Victims of Domestic Violence in Islamic Education Perspective
}

\author{
Bahrul Ma'ani* \\ Ekonomi Syariah, Pascasarjana \\ UIN Sulthan Thaha Saifuddin Jambi \\ Jambi, Indonesia \\ *bahrulmaani2018@gmail.com
}

\author{
Ramlah \\ Ilmu Syariah, Pascasarjana \\ UIN Sulthan Thaha Saifuddin Jambi \\ Jambi, Indonesia
}

\begin{abstract}
This study aims to describe the future challenges of children's education as a result of domestic violence from the perspective of Islamic education. This study uses a qualitative approach with literature review methods. Thus this research is carried out by searching, studying, comparing, and continuing to analyze various document sources that are relevant to the problem being studied. The accuracy or validity of the data is guaranteed through triangulation, the main thing is a triangulation of sources. Based on the data and discussion that has been carried out, it can be concluded that the future challenges of children's education as a result of domestic violence from an Islamic perspective are as follows: (1) Islam (Al-Qur'an and Hadith) prohibits all forms of violence, either In the household as well as in society in general, including the process of children's education, (2) There is a need for special assistance for child victims of domestic violence in the educational process. This can be done through an Islamic education approach, and (3) One of the important keys to the success of children's education in the future from the perspective of Islam is to enforce the law on criminal acts of domestic violence and the kaffah application of Islamic values.
\end{abstract}

Keywords-the future of children's education, domestic violence, an Islamic perspective

\section{INTRODUCTION}

Children as the next generation become the foundation of hopes for the future of the family and nation in the future. $\mathrm{He}$ needs food intake and affection in the household. Therefore he must be nurtured and educated through proper education. And the child referred to under Law Number 23 of 2002 is someone who is not yet 18 years old, including children who are still in the womb [1]. According to Patmonodewo [2], that the development of a person's personality focuses on psychological development stages (0-1 year in the oral sensory stage, stages (3-6) years they are in a stage with autonomy versus shame and doubt crises. Meanwhile, Piaget in Patmonodewo [2], said that cognitive development, development from the sensorimotor stage (0-2 years), preoperational (27 years), concrete operations
(7-12 years), then the cognitive development of preschool children at the preoperational stage.

Therefore, the treatment of children is by the mandate of the provisions of the legislation, and then those who are responsible and should protect children are the State and the government, the community as well as parents and families. The obligations and responsibilities of the state and government in protecting children include: (1) Respecting and guaranteeing the human rights of every child regardless of ethnicity, religion [3] race, class, sex, ethnicity, culture and language, legal status children, birth order, and physical and/or mental condition; (2) Providing support for facilities and infrastructure in implementing child protection. For example, schools, playing fields, sports fields, houses of worship, health centers, art buildings, recreation areas, nursing rooms, daycare centers, and special children's homes; (3) Ensuring the protection, maintenance, and welfare of the child by taking into account the rights and obligations of the parent or guardian or another person who is legally responsible for the child; and (4) Ensure that children exercise their rights in expressing opinions according to the child's age and level of intelligence.

Also guaranteeing preschool education is education to help the growth and spiritual development of students outside the family environment before entering basic education. Kindergarten as a form of preschool education that is in the path of school education is an effort to develop all aspects of the personality of students to bridge education in the school educational family [4]. A harmonious family will be a role model in the family and give birth to smart and happy children, but on the other hand, a family that is not harmonious, especially when violence occurs against the wife and children will give birth to a broken home family, where both parents are not role models in the family.

A family is two or more individuals who are joined by blood, marital relationship, or adoption and they live in a household, interact with each other in their respective roles, and create and maintain a culture. As a culture by interacting 
with the community bring positive things. However, what is often witnessed by a culture of violence is shown almost daily on television, other electronic media, and newspapers that provide information about domestic violence. Even problems like that seem endless, especially the husband's treatment of his wife and children, or vice versa, the unfair treatment of the wife towards her husband. It is undeniable that problems are increasingly occurring due to economic factors, jealousy, and misunderstanding between husbands and wives, resulting in disputes, and children are shown violence by both parents plus other crimes they see through the internet, internet cafes, and other media that can shape children's character into hard and beyond the limits of reasonableness.

\section{METHODS}

This study uses a qualitative approach with literature review methods. This is done because the focus of this research is to describe the challenges of the future of Islamic Child Education as the Impact of Domestic Violence. Thus this research is carried out by searching, studying, comparing, and continuing to analyze various document sources that are relevant to the problem being studied. The accuracy or validity of the data is guaranteed through triangulation, the main thing is a triangulation of sources. Furthermore, after the data is obtained, an in-depth analysis is carried out through critical method analysis which is described descriptively.

\section{DATA AND DISCUSSION}

In terms of domestic violence, there are two pieces of the words "violence" and "household". According to the Latest Indonesian Dictionary, the meaning of "violence" is: (1) An act of a person or group of people that causes injury or death of another person, or causes physical damage or other people's property, or (2) coercion. According to the Big Indonesian Dictionary, violence is a matter (that is, characterized) hard; actions of a person or group of people that cause injury or death of others or cause physical damage or other people's property by coercion [5].

Based on this, violence means the use of physical force to injure or mistreat another person, and then such treatment means deviation, violation, or indecent and cruel speech. There may also be a power that is churning to show its prowess and tends to destroy or compel. Domestic violence is part of the abuse and deviation as well as the destruction of the wife and child if the perpetrator is the husband, but if the perpetrator is the wife it means the destruction of the husband and children, however, this second thing rarely happens.

The term violentia in Latin means violence; ferocity: greatness; venom; cruelty; awesomeness; ferocity; persecution. In American literature, there are several words for "violence" such as tort, battery, and assault. A tort is a wrongful injury to a person's property. Tort that is done intentionally is called "assault" while tort which is done because of negligence is called "battery" [6]. So, the violence is related to acting in inappropriate ways and using physical force that violates the law by injuring oneself, others, and the environment. Likewise in other literature, violence is defined as an attack on one's physical or psychological mental integrity [7].

Anne Grant in her Chusairi [8] work breaking the Cycleaf Violence defines domestic violence as a pattern of deviant and coercive behavior, including physical, sexual, psychological, and economic coercion by adults on their intimate partners. Soerdjono et al. [9] defines violence as a term used for the occurrence of mental or physical injury, which is part of the process of violence which is sometimes allowed, so it is rarely referred to as violence. Society usually makes certain categories regarding behavior that is considered violent or not [8]. The less violence there is in a society, the more worry there is when it occurs. Violence in terminology can be defined as things that are (characterized) hard or the actions of a person or group of people that cause injury or death of a person [10]. It is not stated in the special provisions, but what can be found in the definition of family as stated in article 1 number 30 of Law No. 8 of 1981 on the Criminal Code. Article 1 number 30 reads as follows: family is those who are related to a certain degree by blood or marital relations.

The Domestic Violence Law is a public law in which there is a threat of imprisonment or a fine for violating it, so the wider community, especially men, in the position of head of the family should know what domestic violence is. The nuclear family or also known as the batih family is one that is attended by the father, mother, and children. This family is part of the social institutions that exist in society. For primitive communities whose livelihoods were hunting and farming, the family was a sufficiently adequate structure to handle production and consumption. The family is the basic social institution from which all other institutions develop as an increasingly complex culture becomes an important institution.

As for education or teaching, according to the Big Indonesian Dictionary [11], the word education means a process or method or act of educating. In the language of the definition of education is the process of changing the attitude and behavior of a person or group of people to mature humans through teaching and training efforts [12]. According to UNESCO, education is now engaged in preparations for a life Society that does not yet exist or that education is now to prepare humans for a type of society that does not yet exist. The concept of the education system may change according to the development of society and the transfer of cultural values. The current concept of education cannot be separated from education which must be by the demands of the educational needs of the past, present, and future [4]

Tafsir [11], explained that teaching is an activity that involves fostering children only in terms of cognitive and psychomotor, namely so that children have more knowledge, are more capable of thinking critically, systematically, objectively, and are skilled in teaching something. According to Jones, teaching is a way of preparing learning experiences for students [11]. In other words, teaching is a process practiced by teachers in guiding, assisting, and directing 
students to have a learning experience. Teaching is a process that involves making decisions during pre-teaching, teaching, and post-teaching. Pre-teaching decisions are decisions during curriculum planning and within a teaching unit; decisions during teaching are decisions made during the teaching and learning process, and post-teaching are all decisions made as a result of evaluating the results of the teaching process. This section will only explain planning procedures in the teaching process [13]. Teaching is an effort to utilize or use the knowledge gained to improve the skills, talents, and potentials of a person to face the advancement of the times and as a provision for someone to compete in life [13].

Teaching is a method used or a method used in education to strive to achieve independence and mental maturity from other individuals so that they can survive in their life's competition. The term teaching is defined as the process of presenting material by one person to another with the aim that other people receive, master, and develop the material. The learning material here means something that can be in the form of knowledge, dexterity or skills, activities, and cultural results in general [2].

In essence, the existence of humans as creatures of Allah SWT., since birth, both men and women have been given inherent rights. It is a gift from Him that must be respected, protected by the State, Law, Government, and everyone for the honor and protection of human dignity. The right to science and technology is also a gift from Allah which has brought about many changes in various aspects of life. The advancement of science and technology has had both negative and positive impacts. Contact with foreign socio-culture can change the socio-cultural situation itself; this can change the moral and religious values and principles of society, which in turn will change the attitude of life for the future of children and families.

Al-Quran and al-Hadith teach about the form of a happy household. Like, Q.S. Arrum verse 21 explains to form a harmonious, happy, loving family. Also in Surah al-Nisa 'verse 19 about the social system between husband and wife with mu'asyarah bil ma'ruf. Furthermore, the way both parents behave towards their children is because from birth the child carries a religious nature. This fitrah only functions after going through a process of guidance and training. Religious signs of growing child envy are integrally intertwined with the development of psychological functions in children. Seeing the importance of guidance and maintenance of religious potential from an early age and seeing that there are stages of religious development in children, what is even more important is how the efforts of parents (educators) in fostering a sense of religion in children [6].

Many verses of the Koran and the Sunnah of the Prophet directly or indirectly oblige Muslims to carry out education, especially Islamic religious education, which is aimed at parents of both parents as said by Allah SWT in the Qur'an surah at-Tahrim verse 6: "O you who believe, protect yourself and your family from hellfire". (Surah At-Tahrim: 6).
Morals or characters in Islam are the main targets in education. This can be seen from several hadiths of the prophet which explain the virtues of moral education, one of which is the following hadith: "teach your children better, and educate them". The concept of education in Islam views that humans are born carrying outward potential, namely: 1) the potential to do good to nature, 2) the potential to do damage to nature, 3) the potential of divinity which has non-physical functions. The three potentials are then handed over to human development [4].

Positive law is related to Criminal Law and Family as the smallest social unit in society that plays a major role and has a major influence on the social development and personality development of each child in the family member. Because every human being has the right to feel safe and free from all forms of violence, which are related to domestic violence that is currently rife. It is a violation of human rights and a crime against human dignity as well as a form of discrimination that should be eliminated [14]

The four models of violence listed in the Domestic Violence Law as stipulated in articles 5-9 relating to Article 5 "Every person is prohibited from committing domestic violence against people within the scope of his household, by (a) Physical Violence, (b) Psychic-Violence, (c) Sexual Violence, (d) Domestic Abandonment [15]. Article 6 explains that physical violence as referred to in Article 5 letter a, is an act that causes pain, falls ill, or is seriously injured as a result of actions such as: being hit, slapped, spat on, thrown, grabbed, and kicked. Article 7 also explains that psychological or psychological/psychological violence as referred to in Article 5 letter $b$ is an act that causes fear. Loss of self-confidence, loss of ability to act, feeling helpless, and/or severe psychological suffering in a person. Violence experienced by someone that does not cause marks such as physical violence, but this psychological violence can undermine self-esteem and others [16].

Domestic Violence, a form of vulnerability in household life, is increasingly visible due to the weak joints of the household economy, lack of appreciation and practice of religion, the influence of communication media that makes it easier for people to interact by ignoring the moral norms that have prevailed in the society. Everyone longs for a happy and prosperous family, sakinah, mawaddah, and rahmah, but not always the ark of domestic life can be lived well and smoothly as expected by most people. Communication between the two husbands and wives can occur because of a misunderstanding or deliberately make by one of the parties. If there is disharmony in the household, it can be resolved by the two partners (husband-wife), or by kinship and mediation or also taking legal action in the Religious Court, which may end up being peaceful or divorced accompanied by rational and logical considerations. For this reason, the religious court is a specification forum to convey aspirations for problem families and communities to seek justice, but not all problem families are brought to court [14]. It also does not rule out the possibility that family cases can be resolved internally with 
husband and wife, some cases are resolved by involving external parties or third parties using mediation services or rights that are also called arbitration and some cases are consciously and recollection of promises. Taklik talak which has been uttered so that by violating the promise of shighat some have entered the process at the religious court [17]. Based on the promise made after the completion of the marriage contract or called taklik talak, it should be an early warning for married couples not to commit Domestic Violence (KDRT) is a synchronization of the creation of His creation as a couple so that the harmonization of the relationship takes place [18].

Because everyone wants the wholeness and harmony of a happy, safe, peaceful, and peaceful household is great hope for everyone in the household. To realize wholeness and harmony depends on everyone in the scope of the household, mutual understanding, mutual care, nurture and compassion, and selfcontrol in dealing with problems [19]. Within the household, tensions and conflicts are common. Disagreements, arguments, fights, muttering, or even cursing are common things, but it is mentally painful so this kind of situation is already another matter.

Today, people are faced with many forms of violence, the most common of which is domestic violence or against other couples who experience abuse from their loved ones. Sometimes a person repeatedly experiences or experiences targets of violence in the form of physical, psychological, sexual violence, and fear (traumatic) because one partner forces a woman to do something she wants without paying attention to women's rights, resulting in torture called Domestic Violence.

This is a deviant behavior for a husband towards his wife who may very well hinder the increase in the productivity of the quality of life in both the family to build a sakinah, mawaddah, warahmah families in one's environment or on a national scale [20]. In the case of family, it is an important asset to develop human resources as a whole, which is reflected through physical and spiritual health. Because these two aspects will be realized when spiritual health can be fulfilled and physical health can be fulfilled [18].

Violence is a trendy phenomenon and often occurs in the family and the social sphere, both in big cities and in rural areas. This can be seen based on the recapitulation of reports on cases of Domestic Violence, women, and children due to the Jambi City Religious Court in the period 2018 and 2019.

Based on this data, it can be explained that there are 11 Districts in the city of Jambi, but only 6 Districts were taken as the highest cases of domestic violence, violence against children, and violence against women for 2018/2019. For example, (1) Kec. East Jambi in 2018, domestic violence was indeed 0 (non-existent), violence against children was 2 , and violence against women was 1 person. But in 2019, there was a sharp increase in domestic violence 1 , violence against children 8 people and violence against women 3 people. (2) Kec. Kota Baru, in 2018, KDRT 1 person, violence against children 5 people and violence against women 1 person. However, in
2019 there was a sharp increase in domestic violence for 8 people, violence against children 9 people, and violence against women 0 (none). (3) Kec. South Jambi in 2018, domestic violence 2 people, violence against children 1 person and violence against women 0 (none). However, in 2019 there was a sharp increase in domestic violence for 3 people, violence against children 12 people, and violence against women 0 (none). (4) Kec. Telanaipura in 2018, KDRT 1 person, violence against children 2 people and violence against women 1 person. However, in 2019 there was a sharp increase in domestic violence for 6 people, violence against children 1 person, and violence against women 0 (none). (5) Kec. Jambi Market in 2018, domestic violence for 3 people, but violence against children 1 person and violence against women 0 (none). However, in 2019, there was a sharp increase in domestic violence for 3 people, violence against children 1 person, and violence against women 0 (none). (6) Kec. Jelutung in 2018 domestic violence 0 people, violence against children 1 and violence against women 0 (none). However, in 2019 there was a sharp increase in domestic violence for 1 person, violence against children for 6 people, and violence against women 0 (none).

Based on the data above, cases of violence against children are more than domestic violence and women's violence, meaning that they are related to the impact of education and children's psychology which can make everyone aware of the causes of increasing cases of Domestic Violence (KDRT). That is the urgency of taking preventive, repressive, preventive, and curative steps regarding the tendency of increasing violence both in the family and society. The efforts of the Jambi City Religious Court to act to create a sense of comfort and tranquillity in the household through law enforcement as well as assisting the community in understanding actions those are detrimental to the family. Therefore, the law is often referred to as a social phenomenon, meaning that where there is a community or society there is the law. The existence of law is a necessity of society, both individually and collectively, namely the establishment of interactions with others to get along with each other. The law is very much needed in a simple to the broad association because the law is the basis for the rules of the game in the system of life.

Also, the influence of information technology has an impact on the patriarchal culture of domestic violence, so that the husband as the head of the family is still considered superior to women which at any time can trigger cases of Domestic Violence and women do not dare to report to the authorities or the Religious Court. The essence of the concept of violence is an arbitrary deprivation of liberty that results in misery, threats, coercion in private life or public [16]. Violence against women and children in the household can include all forms of physical, sexual, psychological, and economic violence that can cause feelings of discomfort and prolonged suffering, pain, injury, health damage, and neglect of physical and mental livelihood obligations.

According to Kaligis [21], Legal Protection for Women in Domestic Violence is an effort to protect the law against 
women, especially victims of Domestic Violence and this is not only at the level of law enforcement implementation, but also accommodated for the needs of the community, especially women and children to continue their education as a victim of Domestic Violence in the form of a law that truly guarantees legal protection for himself and society in general. This is where the role of legislative policies in criminal policy is needed to accommodate women's needs for legal protection, especially in cases of domestic violence.

Domestic violence will inhibit children's cognition which is interpreted as intelligence or thinking. Cognitive also means a broad understanding of thinking and observing, so it is a behavior that results in people acquiring knowledge or what is needed to use knowledge. So the behavior of the parents (fathers and mothers) is seen and imitated by the child, if it is good it will have a good effect on the child, and if it is bad what is done by both parents then there is a bad precedent for the child. Cognitive development in children is explained by various theories and various terms. The viewpoint of behaviorism argues that the growth of intelligence through the collection of information is increasing, while the "interactionism" or "developmental" flow argues that knowledge comes from interactions between children and the child's environment. Furthermore, it is argued that the development of intelligence is influenced by the factors of maturity and experience [22].

Law Enforcement of Domestic Violence Crimes reveals that the implementation of security forces in law enforcement for criminal acts of domestic violence is generally by the applicable law. Also to show that several things have not been fulfilled by the authorities in enforcing the Domestic Violence law, namely relating to the rights of victims such as obtaining legal assistance during the examination process by statutory provisions, socialization, advocacy on domestic violence. However, sometimes they are constrained, they are ashamed of being known by their neighbors, and they are afraid that if they do not report, no one can support their family life. As a result, a divorce could occur due to the Violent Torture of the Wife and end up in front of the court.

\section{CONCLUSION}

Based on the description above, at the end of this study it can be concluded that the future challenges of Islamic children's education as a result of domestic violence, there are several important points in conclusion, namely as follows:

- Islam (Al-Qur'an and Hadith) prohibits all forms of violence, both within the household and in society in general, including in the process of children's education.
- There is a need for special assistance for child victims of domestic violence in the educational process. This can be done through an Islamic education approach.

- One of the important keys to the success of children's education in the future from the perspective of Islam is the law enforcement of criminal acts of domestic violence.

\section{REFERENCES}

[1] M.H. Umar and B. Ma'ani, "Urgensi Hak dan Perlindungan Anak dalam Perspektif Maqashid Al-Syariah," Al-Risalah, vol. 17, no. (02), pp. 201212, 2018.

[2] S. Patmonodewo, Pendidikan Anak Prasekolah. Jakarta: PT. Rineka Cipta, 2003.

[3] Yusdani, Peranan Kepentingan Umum dalam Reakltualisasi Hukum: Kajian Konsep Hukum Islam Najamuddin al-Thufi. Yogyakarta: UII Press, 2000

[4] L.A. Ma"shumah, Pembinaan Kesadaran Beragama Pada Anak, dalam Ismail SM (eds), Paradigma Pendidikan Islam. Yogyakarta: Pustaka Pelajar, 2001.

[5] Team Reality, Kamus Terbaru Bahasa Indonesia. Surabaya: Realita Publisher, 2008.

[6] A. Wahid, Islam Tanpa Kekerasan. Yogyakarta: LK1S, 1998.

[7] M. Fakih, Analisis Gender dan Transformasi Sosial, cet. IV, Yogyakarta: Pustaka Pelajar, 1999.

[8] A. Chusairi, Mengejar Harmoni. Yogyakarta: Rifka Annisa WCC, 2000.

[9] Soerdjono, dkk., Kamus Kriminologi. Jakarta: Ghalia Indonesia, 1985.

[10] Pusat Pembinaan dan Pengembangan Bahasa Indonesia, Kamus Besar Bahasa Indonesia. Jakarta: Balai Pustaka, 1994.

[11] A. Tafsir, Metodologi Pengajaran Agama Islam. Bandung: PT. Remaja Rosdakarya, 1995.

[12] P.B. Horton, Sosiologi. Jakarta: Erlangga, 1987.

[13] Ign.S. Ulihbukit Karo-karo, et al., Metodologi Pengajaran. Salatiga: CV. Saudara, 1981.

[14] B. Waluyo, Pidana dan Pemidanaan. Jakarta: Sinar Grafika, 2000.

[15] Konsideran tentang Penghapusan Kekerasan Terhadap Rumah Tangga dalam Undang-Undang Republik Indonesia, No. 23 Tahun 2004.

[16] R.S. Kolibonso, "Kejahatan itu bernama kekerasan dalam rumah tangga," Jurnal Perempuan, vol. 25, pp. 7-21, 2002.

[17] J. Mubarok, Modernisasi Hukum Perkawinan Di Indonesia. Bandung: Pustaka Bani Quraish, 2005.

[18] F.A. Yasin, Risalah Hukum Nikah. Surabaya: Terbit Terang, 2006.

[19] N. Ainiyah, "Pembentukan Karakter Melalui Pendidikan Agama Islam," Jurnal: Al-Ulum, vol. 13, no. (1), Juni 2013.

[20] L. Salam, Menuju Keluarga Sakinah, Mawaddah,Warohmah. Surabaya: Terbit Terang, 2006.

[21] O.C. Kaligis, Reformasi Hukum Pidana Melalui Perundangan dan Peradilan. Bandung: PT. Alumni, 2002.

[22] N. Sulhan, Pendidikan Berbasis Karakter Sinergi antara Sekolah dan Rumah dalam Membentuk karakter Anak. Surabaya: Jaringpena, 2010. 